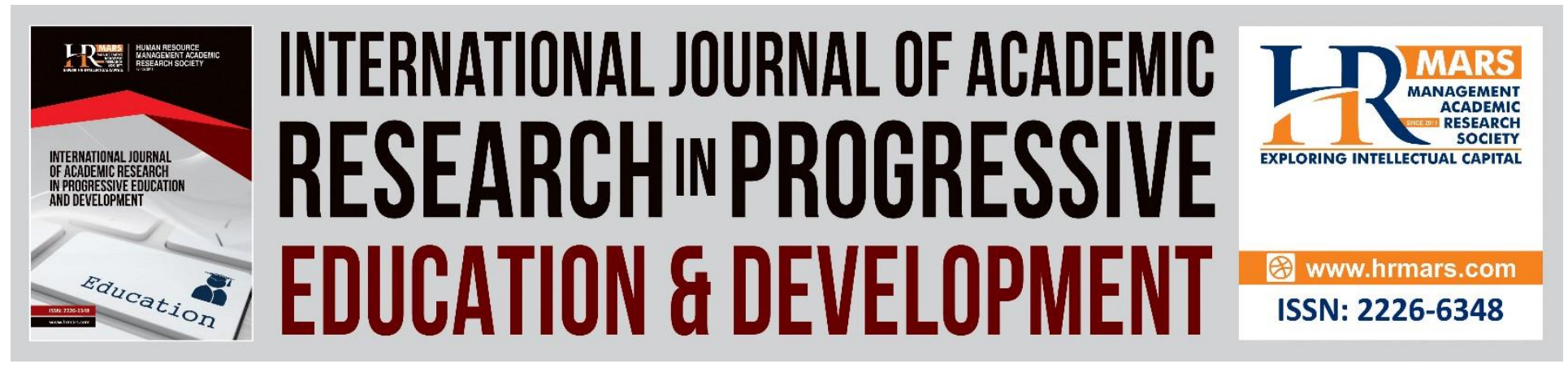

\title{
Pre-Service Teachers' Perceptions towards the Use of Digital Technologies in Schools
}

Or-Kan, Soh \& Nurr Fatihah Binti Ahmad

To Link this Article: http://dx.doi.org/10.6007/IJARPED/v7-i4/5086 DOI: 10.6007/IJARPED/v7-i4/5086

Received: 06 Nov 2018, Revised: 19 Dec 2018, Accepted: 22 Dec 2018

Published Online: 26 Dec 2018

In-Text Citation: (Or-Kan \& Ahmad, 2018)

To Cite this Article: Or-Kan, S., \& Ahmad, N. F. B. (2018). Pre-Service Teachers' Perceptions towards the Use of Digital Technologies in Schools. International Journal of Academic Research in Progressive Education and Development, 7(4), 349-363.

\section{Copyright: (C) 2018 The Author(s)}

Published by Human Resource Management Academic Research Society (www.hrmars.com)

This article is published under the Creative Commons Attribution (CC BY 4.0) license. Anyone may reproduce, distribute, translate and create derivative works of this article (for both commercial and non-commercial purposes), subject to full attribution to the original publication and authors. The full terms of this license may be seen

at: http://creativecommons.org/licences/by/4.0/legalcode

Vol. 7, No. 4, 2018, Pg. 349 - 363

http://hrmars.com/index.php/pages/detail/IJARPED

JOURNAL HOMEPAGE

Full Terms \& Conditions of access and use can be found at http://hrmars.com/index.php/pages/detail/publication-ethics 


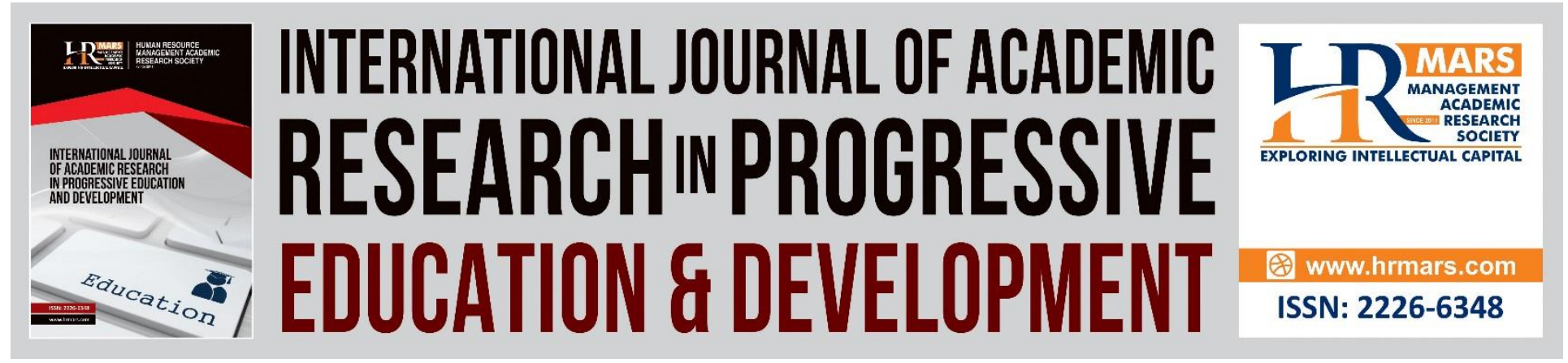

\title{
Pre-Service Teachers' Perceptions towards the Use of Digital Technologies in Schools
}

\author{
Or-Kan, Soh \& Nurr Fatihah Binti Ahmad \\ The School of Language Studies \& Linguistics, Universiti Kebangsaan Malaysia, Malaysia \\ 43600 UKM Bangi, Selangor, Malaysia. \\ Email: sok@ukm.edu.my
}

\begin{abstract}
Technology that has been rapidly developing in this current era has changed our way of life, including the method of teaching which is slowly being shifted to the modern way of teaching while still pertaining the traditional method of teaching. Many students know how to use digital technologies while some are still awkward in using digital technologies. Pre-service teachers need to be aware of this matter. Thus, it is important to investigate the perception of the pre-service teachers towards the use of digital technologies as the teachers are going to lead learners towards the current era. This study aims to investigate on the perception of the pre-service teachers towards the use of digital technologies in schools. The researcher conducted this study at $\mathrm{ukm}$ with fpend students as the sample of population. A quantitative approach is used in this study which is by distributing survey questionnaire to the subjects. Utaut model is used as the theoretical framework. Findings show that performance expectancy and social influences have a significant relationship with the pre-service teachers' behavioural intention in using digital technologies at schools. Whereas facilitating conditions show a significant relationship with the pre-service teachers' behaviour in using the digital technologies. This study contributes to becoming future guidelines and references for further research on the same topic background.

Keywords: Pre-Service Teachers, Perceptions, Digital Technologies, Schools, Quantitative
\end{abstract}

\section{INTRODUCTION}

Information and Technology (ICT) was introduced in Malaysia during the 1970s, and in 1999, computer education program was started. Next, the use of technology in the education system was further developed in 2003 onwards (Habibah, Muniandy, 2010). According to Levin \& Wadmany (2008), new possibilities and problems were created by ICT which eventually urges educators to make teaching and learning in a more meaningful way. Ramasamy (2006), stated that ICT plays a big role in the present and up-to-date educational practice. Habibah, Muniandy (2010) further added, schools in Malaysia is provided with a computer lab and IT educators to assist students in gaining knowledge about technology. 
There are several past studies done on technology including perceptions of pre-service teachers on web 2.0 technologies (goktalay \& ozdilek 2010; eyyam, menevis, \& dogruer 2011), teachers' attitude towards technology (albirini 2006), influence of gender and computer teaching efficacy (wong, teo, \& russo 2012), and others regarding technology aspect with teachers and students as a focus of their studies. Nevertheless, only a few number of studies could be found on digital technologies with pre-service teachers as a focus in the past few years. Furthermore, studies on perception of pre-service teachers towards digital technologies can only be found in a small amount of number locally. Thus, this study has been conducted with aims to study on perceptions towards the use of digital technologies in schools.

\section{RESEARCH OBJECTIVE}

The aim of this study is to study on the perceptions of pre-service teachers towards the use of digital technologies in schools. Thus, the researcher came out with one objective concurring to the aim of this study, which is as followed:

To investigate to what extent do the determinants below encourage or restrain the preservice teachers.
I. Performance expectancy
li. Effort expectancy
lii. Social influence
Iv. Facilitating conditions

\section{LITERATURE REVIEW}

\section{THEORETICAL FRAMEWORK}

In correlation to the research questions of this study, the researcher used theory on unified theory of acceptance and use of technology (utaut) to investigate the determinants that encourage or restrain the pre-service teachers. Theory of acceptance and use of technology (utaut) aims to explain the user intention to use an information system and the following usage behaviour that are considered to be manipulated by four key concepts which are performance expectancy, effort expectancy, social influence and facilitating conditions. 
Vol. 7, No. 4, 2018, E-ISSN: 2226-6348 @ 2018 HRMARS

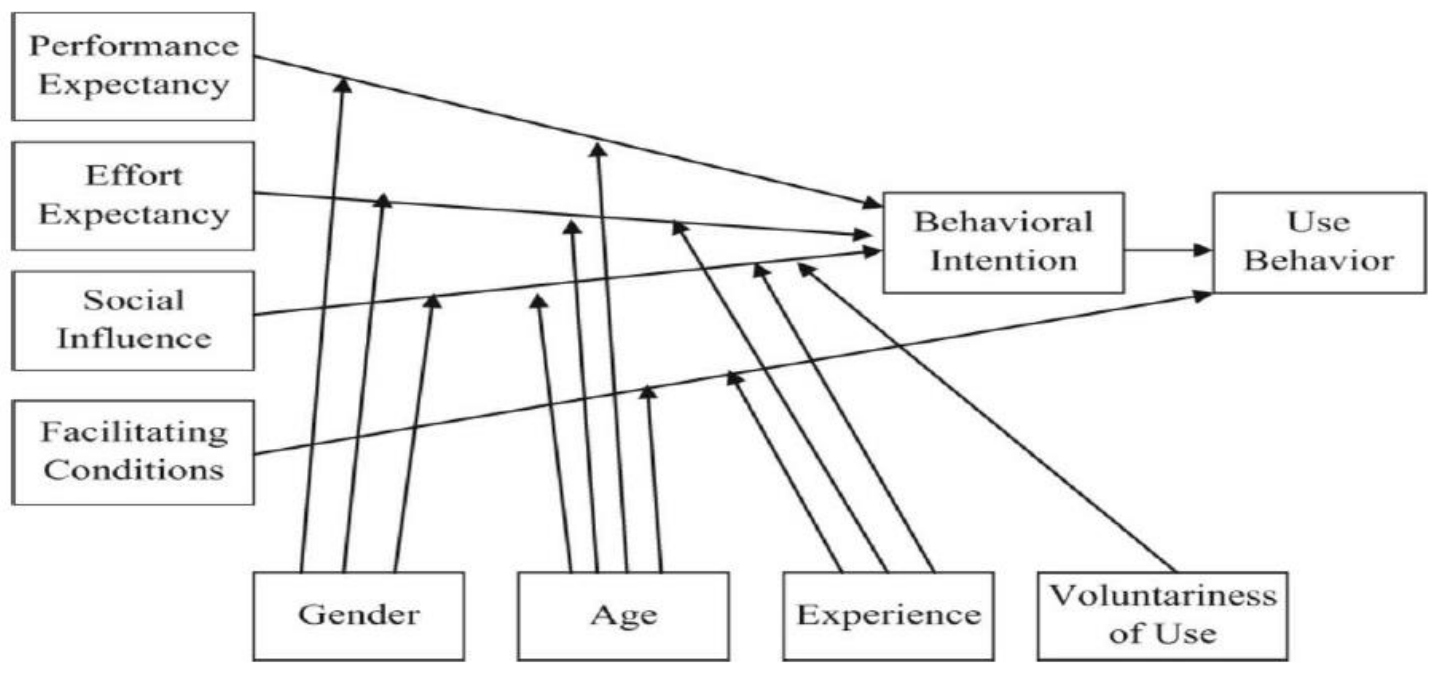

Figure 2.1 Theory of Acceptance and Use of Technology (UTAUT)

\section{RESEARCH HYPOTHESES}

The unified theory of acceptance and use of technology (utaut) was created by venkatesh et al (2003) with aims to describe the user acceptance towards technology. Alshehri stated that "venkatesh et al (2003) created this synthesized model to present a complete picture of the acceptance process than was possible with any previous individual models" (2012: 72). The four key constructs that the theory holds are performance expectancy, effort expectancy, social factors and facilitating conditions. Performance expectancy, effort expectancy, and social factors are direct determinants of behavioural intention, followed by facilitating conditions that are a direct determinant towards use behaviour, as shown in figure 2.1 above. Other than that, the utaut model also contains four variables or known as moderators which are age, gender, experience and voluntariness of use.

However, in this current research, the researcher did not take into account the four moderators which are age, gender, experience and voluntariness of use. This is due to this study only focuses on the perception of pre-service teachers towards digital technology without taking any consideration of age, gender, experience, and voluntariness of use. In accordance with a study done by $\tan$ (2013), the four moderators are not considered due to the sample of a population of the researcher are college students and thus, making the four moderators having similar aspects. Furthermore, teo and noyes stated that "the scales used in the utaut model are a combination of a number of prior scales, and therefore, their suitability needs to be tested further" (2014: 53). This is due to the initial utaut research was concentrated in the business environments on large associations (teo \& noyes 2014). 
INTERNATIONAL JOURNAL OF ACADEMIC RESEARCH IN PROGRESSIVE EDUCATION AND DEVELOPMENT

Vol. 7, No. 4, 2018, E-ISSN: 2226-6348 @ 2018 HRMARS

Hence, this study modified the Unified Theory of Acceptance and Use of Technology (UTAUT) using pre-service teachers as a sample in explaining the determinants that affect the pre-service teachers in an educational environment as follow:

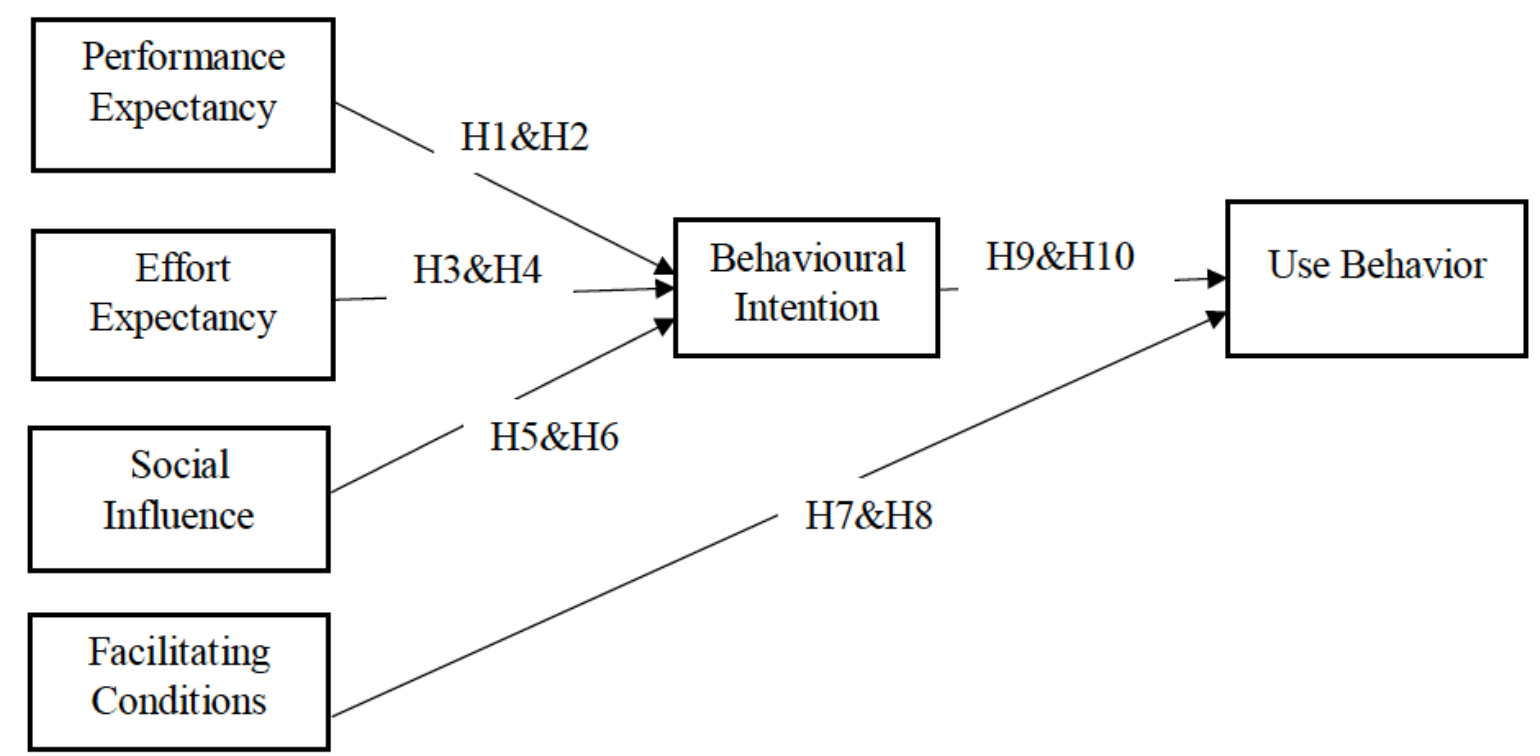

Figure 2.2 The Modified Theory of Acceptance and Use Technology (UTAUT)

According to Venkatesh et al (2003), the four key constructs are defined as below:

1. PERFORMANCE EXPECTANCY: The degree to which a person believes that they will attain advantages or improvements in job performance if they are using the system. Thomas, singh, and gaffar (2013), further added that performance expectancy can be regarded as the perceived usefulness of the technology.

2. Effort Expectancy: The degree of ease of use of technologies.

3. SOCIAL INFLUENCES: The degree to which an individual perceives that other's perception is important in believing that the individual should use the system.

4. FACILITATING CONDITIONS: The degree to which an individual believes that infrastructures exist to support the existence of technology and the use of it.

According to Venkatesh et al (2003), performance expectancy, effort expectancy, and social influences are independent variables which will influence the dependent variable behavioural intention. Whereas, behavioural intention act as an essential predictor of the use behaviour. Facilitating conditions is the independent variable that will influence the dependent variable use behaviour. 
INTERNATIONAL JOURNAL OF ACADEMIC RESEARCH IN PROGRESSIVE EDUCATION AND

DEVELOPMENT

Vol. 7, No. 4, 2018, E-ISSN: 2226-6348 @ 2018 HRMARS

This study theorizes the hypothesis of the modified utaut model as below:

\section{PERFORMANCE EXPECTANCY.}

Hypothesis 1: The performance expectancy influences the behavioural intention in encouraging the pre-service teachers in using digital technology in schools.

Hypothesis 2: The Performance Expectancy Influences The Behavioural Intention In Constraining The Pre-Service Teachers In Using Digital Technology In Schools.

\section{EFFORT EXPECTANCY.}

Hypothesis 3: The effort expectancy influences the behavioural intention in encouraging the preservice teachers in using digital technology in schools.

Hypothesis 4: The effort expectancy influences the behavioural intention in constraining the preservice teachers in using digital technology in schools.

\section{SOCIAL INFLUENCE.}

Hypothesis 5: Social influence situations influences the behavioural intention in encouraging the pre-service teachers in using digital technology in schools.

Hypothesis 6: Social influence situations influences the behavioural intention in constraining the pre-service teachers in using digital technology in schools.

\section{FACILITATING CONDITIONS}

Hypothesis 7: Facilitating conditions influences the use behaviour in encouraging the pre-service teachers in using digital technology in schools.

Hypothesis 8: Facilitating conditions influences the use behaviour in constraining the pre-service teachers in using digital technology in schools.

\section{BEHAVIOURAL INTENTION.}

Hypothesis 9: Behavioural intention influences the use behaviour in encouraging the pre-service teachers in using digital technology in schools.

Hypothesis 10: Behavioural intention influences the use behaviour in constraining the pre-service teachers in using digital technology in schools.

\section{DETERMINANTS OR CONSTRAINTS FOR TEACHERS}

Tan (2013) done a research on determining the factors that affecting e-learning websites. In the study, the researcher state that online learning websites are vastly used by college students and have no learning limits due to the evolution of the internet. The researcher used unified theory of acceptance and use technology in conducting the research and conducted it using a quantitative method which is a survey questionnaire. A total of 176 taiwanese college student answered the questionnaire and the collected data shows positive results overall. The findings show that performance expectancy, effort expectancy, and facilitating conditions has a significant relationship with behavioural intention. Meanwhile, social influences and behavioural intention also found to be significant to the use behaviour. 
DEVELOPMENT

Vol. 7, No. 4, 2018, E-ISSN: 2226-6348 ๑ 2018 HRMARS

However, Attuquayefio \& Addo (2014) suggests that only effort expectancy significantly influences students' behavioural intention. On the other hand, facilitating conditions significantly influences the use behaviour in using ICT for learning and research. Whereas, the other independent variables show insignificant relationship to the dependent variable. Contrast to Alshehri (2012), the study suggests that only social influences did not significantly influence behavioural intention and use behaviour.

Baltaci-Goktalay and Zehra (2010) study on the perceptions of pre-service teachers towards web 2.0 technologies and found that most of the pre-service teachers had a positive attitude and high level of acceptance in using web 2.0 technologies. The respondents of the study consist of 43 pre-service science teachers and 58 pre-service computer teachers. The researchers also found that the respondents are willing to use web 2.0 to support the courses in their respective programs. However, findings found by baltaci-goktalay and zehra could be further improved by using a more coherent method to analyse the collected data instead of using only spss descriptive statistics. Although the researchers use utaut questionnaire adapted from venkatesh et al. (2003) in one section of their survey questionnaire to conduct the research, the findings of the utaut model is a bit ambiguous as it did not clearly state the results.

The differences in the findings of all the above studies may be due to a number of reasons. Some of the apparent reasons are the number of sample of the population are not in the same range, different types of participants were involved, the studies were conducted in different countries and the different method used to analyse the collected data. In the past studies above, Tan (2013) included 176 students in conducting the research at a college in Taiwan and uses SPSS to analyse the collected data. Whereas, Attuquayefio \& Addo (2014) include a larger number of the sample of a population which is 345 students at a university in Ghana and use SPSS 16 and AMOS 20 to analyse the collected data. Meanwhile, Baltaci-Goktalay and Zehra (2010) include a total number of 101 pre-service teachers at a university in Turkey and analyse the collected data using SPSS 16 . All of the above studies used quantitative research method in conducting their studies.

\section{RESEARCH METHODOLOGY RESEARCH DESIGN}

The research design that is applied in this study is a quantitative research method. A quantitative approach is usually used for empirical logic, which is to determine whether the hypotheses being made earlier in the research are supported or not supported. The hypotheses can be determined by collecting data from the targeted sample of the population. Quantitative approach is suitable with this study as the researcher for this current study desired to study on the perceptions of the pre-service teachers and as well as testing the hypotheses.

A quantitative approach in this study used a survey method in order to collect data from the sample of the population of the respondents that have been identified through convenience sampling technique. Barbie (2000) stated that survey method is the best method of collecting data from a large number of the population through a sampling technique. 


\section{SAMPLE OF POPULATION}

In this study, the researcher has decided to list down certain criteria that the respondents need to have in order for them to involve in this study. The respondents must have these criteria that have been listed down as follows:

1. Respondents must be in a range of the first year to fourth year students at faculty of education (fpend).

2. Respondents must be majoring in one of the courses that the faculty of education (fpend) has offered.

3. Respondents must be undergraduates' students and local citizens in malaysia.

\section{RESEARCH INSTRUMENTS}

Since this study involves a large sample of the population, the researcher decided to use the questionnaire as the research instruments. Furthermore, by using questionnaire, it is compatible with the views of barbie (2000) and frankel and wallen (2004) which suggests that the method used is the easiest and effective for a large size of a sample of the population. Moreover, according to cornford and smithson (1997) and miles and huberman (1994) as cited by al-shafi and weerakkody (2009), using the questionnaire as the main data collection are low-cost, timesaving and it able to provides a scale from a large size of the sample from a research.

Jackson (2006) stated that the accuracy of the respondents in answering the questionnaire could be achieved due to the absentee of the researcher. The absence of the researcher consequently encourage the respondents to give more accurate and correct answers. Furthermore, according to Wiersma (2000), a survey questionnaire is one of the instruments that is very effective to use in a different situation and location. This is because it is effective and suitable to investigate a local community to the extent of international level of research. Moreover, the capability of questionnaire to investigate a large sample of population will increase the accuracy population parameter of the estimated sample of statistics.

\section{PROCEDURES}

This research is conducted at the national university of malaysia (ukm) and is focused on faculty of education (fpend) as the target participants of this present study is pre-service teachers. A survey questionnaire has been adapted from past studies that correlate with the title of this study and was further adjusted to fit with the aim of this present study. The targeted students must follow the criteria that have been mentioned above, which are respondents must be students in a range from the first year to the fourth year, majoring in one of the courses in fpend and must be undergraduates' students with malaysian nationality.

The survey questionnaire that has been adapted are handed to the participants manually. This is to ensure that the respondents return the questionnaire back to the researcher instead of keeping it to themselves. An online survey using google forms would be easier to conduct as it is 

DEVELOPMENT

Vol. 7, No. 4, 2018, E-ISSN: 2226-6348 @ 2018 HRMARS

time efficient, however, the possibility of the students not completing the questions being asked and the number of participants required are not enough are being risked. Thus, the researcher decided to hand the questionnaire form manually to the targeted respondents.

Next, after the targeted amount of respondents are sufficient, the data is analysed using statistical package for social sciences (spss) version 23.0. Spss is a software for a computer that is capable of handling a large amount of data. Hence, it is suitable to use spss in analysing the data as this study has 100 respondents as a sample of the population.

\section{DATA ANALYSIS}

The collected data is analysed using statistical package for social sciences (spss) version 23 as this software is capable of handling a large amount of data and can perform numerous analysis. The researcher uses reliability analysis, and regression analysis to analyse the collected data in this study.

\section{RESULTS}

\section{REGRESSION ANALYSIS}

In this study, the researcher used regression analysis to identify the influences of performance expectancy, effort expectancy, and social influence on behavioural intention. Furthermore, regression analysis is once again used to identify whether the facilitating condition and behavioural intention significantly affecting the use behaviour.

Table 4.1a Regression between Performance Expectancy, Effort Expectancy, Social Influence and Behavioural Intention

\begin{tabular}{|c|c|c|c|c|c|}
\hline Variables & $\beta$ & t-value & p-value & F-value & P-value \\
\hline (constant) & & .091 & .928 & \multirow{5}{*}{32.234} & \multirow{5}{*}{.000} \\
\hline $\begin{array}{l}\text { Performance } \\
\text { Expectancy }\end{array}$ & .339 & 3.729 & .000 & & \\
\hline Effort Expectancy & 220 & 2.475 & .015 & & \\
\hline Social Influence & .292 & 3.175 & .002 & & \\
\hline$R^{2}$ & \multicolumn{3}{|l|}{.502} & & \\
\hline
\end{tabular}

Table 4.1 shows that $r 2$ value is 0.502 which means that performance expectancy, effort expectancy, and social influence are $50.2 \%$ of the variation of behavioural intention. Anova result shows the fit of the regression model where the model is a significant fit of the data $(f=32.234$, $p=.000)$. In terms of relationship between the variables, there is a significant relationship between performance expectancy and behavioural intention $(\beta=0.339, p=.000)$. However, effort expectancy and behavioural intention did not shows a significant relationship $(\beta=0.220, p=0.015)$ 
INTERNATIONAL JOURNAL OF ACADEMIC RESEARCH IN PROGRESSIVE EDUCATION AND

DEVELOPMENT

Vol. 7, No. 4, 2018, E-ISSN: 2226-6348 @ 2018 HRMARS

due to the value of $p>0.05$. Whereas, social influence shows a significant relationship with behavioural intention where the values of $p<0.05(\beta=0.292, p=0.002)$.

Table 4.1b Regression between Facilitating Condition, Behavioural Intention and Use Behaviour

\begin{tabular}{|c|c|c|c|c|c|}
\hline Variables & $\beta$ & t-value & p-value & F-value & P-value \\
\hline (constant) & & 4.03 & .000 & \multirow[t]{4}{*}{77.834} & \multirow[t]{4}{*}{.000} \\
\hline Facilitating & .222 & 2.56 & .012 & & \\
\hline Behavioural & .616 & 7.11 & .000 & & \\
\hline$R^{2}$ & \multicolumn{3}{|l|}{.616} & & \\
\hline
\end{tabular}

Table $4.1 \mathrm{~b}$ shows the $\mathrm{R} 2$ value of 0.616 which indicates that facilitating conditions and behavioural intention are $61.6 \%$ of the variation of the use behaviour. ANOVA shows that there is a fit of the regression model where the model is a significant fit of the data $(\mathrm{F}=77.834, \mathrm{P}=.000)$. There is no significant relationship between facilitating conditions and use behaviour $(\beta=0.222, p=0.012)$ where $p>0.05$. Meanwhile, behavioural intention and use behaviour shows a significant relationship $(\beta=0.616, p=.000)$.

\section{DISCUSSIONS}

The utaut model that is used in this study is derived from venkatesh et al. (2003). Venkatesh et al. (2003) indicates that performance expectancy, effort expectancy and social influence directly influence behavioural intention which will subsequently give direct influence to the use behaviour. Whereas, facilitating condition has a direct influence on use behaviour.

In this study, the results shows that performance expectancy and social influence significantly affecting behavioural intention of the pre-service teachers in using digital technologies in schools. This result is coherent with the initial result found by venkatesh et al (2003) and results found by past researcher, $\tan (2013)$. However, the result is inconsistent with results found by birch \& irvine (2009). Whereas, effort expectancy insignificantly affecting the behavioural intention and opposes the initial results by venkatesh et al (2003) but shows consistency with birch \& irvine (2009). Furthermore, facilitating condition showcases insignificant with use behaviour where this contradicts with original results by venkatesh et al (2003) and attuquayetio \& addo (2014). The results further shows that behavioural intention shows significant effects towards use behaviour which consistent with the initial results found by venkatesh et al (2003) and bing tan (2013). However, it shows inconsistency with results found by attuquayetio \& addo (2014).

According to the findings that have been found from the survey questionnaire, hypotheses in this study can be confirmed either it is supported or denied. Table 4.1a indicates 


\section{INTERNATIONAL JOURNAL OF ACADEMIC RESEARCH IN PROGRESSIVE EDUCATION AND}

\section{DEVELOPMENT}

Vol. 7, No. 4, 2018, E-ISSN: 2226-6348 @ 2018 HRMARS

the findings for performance expectancy, effort expectancy and social influence towards the behavioural intention. Whereas Table $4.1 \mathrm{~b}$ shows the results for facilitating conditions and behavioural intention towards use behaviour. Hence, the findings in Table 4.1a and Table 4.1b could answer hypothesis 1 until hypothesis 10.

\section{PERFORMANCE EXPECTANCY}

Hypothesis 1: The performance expectancy influences the behavioural intention in encouraging the pre-service teachers in using digital technology in schools.

Hypothesis 2: The performance expectancy influences the behavioural intention in constraining the pre-service teachers in using digital technology in schools.

The results in table 4.2.3a indicates that performance expectancy positively affecting user's behavioral intention in using digital technologies in schools $(\beta=0.339, p=.000)$. Hence, it can be said that hypothesis 1 is supported whereas hypothesis 2 is denied. This is due to when the users expect that their performance will increase while using digital technologies, so does their intention to use the digital technologies.

\section{EFFORT EXPECTANCY}

Hypothesis 3: The effort expectancy influences the behavioural intention in encouraging the preservice teachers in using digital technology in schools.

Hypothesis 4: The effort expectancy influences the behavioural intention in constraining the preservice teachers in using digital technology in schools.

The results in Table 4.2.3a shows that effort expectancy has no significant relationship with behavioural intention which means that it affects the users' negatively $(\beta=0.220, p=0.015)$. Thus, this indicates that hypothesis 3 is denied and hypothesis 4 is supported. This means that when users' expect that digital technologies are hard and complicated to use, their behavioural intention to use digital technologies in schools will decrease.

\section{SOCIAL INFLUENCE}

Hypothesis 5: Social influence situations influences the behavioural intention in encouraging the pre-service teachers in using digital technology in schools.

Hypothesis 6: Social influence situations influences the behavioural intention in constraining the pre-service teachers in using digital technology in schools.

The results in Table 4.2.3a shows that social influence positively affects users' behavioural intention in using digital technologies as it has a significant relationship $(\beta=0.292, p=0.002)$. Thus, hypothesis 5 is supported and hypothesis 6 is denied. This means that when the users' expect that social influences from people who are important to them suggest them to use digital technologies, it will increase their intention to use digital technologies.

\section{FACILITATING CONDITION}

Hypothesis 7: Facilitating conditions influences the use behaviour in encouraging the pre-service teachers in using digital technology in schools. 
INTERNATIONAL JOURNAL OF ACADEMIC RESEARCH IN PROGRESSIVE EDUCATION AND

DEVELOPMENT

Vol. 7, No. 4, 2018, E-ISSN: 2226-6348 ๑ 2018 HRMARS

Hypothesis 8: Facilitating conditions influences the use behaviour in constraining the pre-service teachers in using digital technology in schools.

The results in Table 4.2.3b indicates that the facilitating conditions have a negative effect on users' behaviour to use the digital technologies $(\beta=0.222, p=0.012)$. Thus, hypothesis 7 is denied and hypothesis 8 is supported. This means that the when the users' expect facilitating conditions such as digital technologies support from the universities, individual or group of people were not received, it will decrease their behaviour to use the digital technologies.

\section{BEHAVIOURAL INTENTION}

Hypothesis 9: Behavioural intention influences the use behaviour in encouraging the pre-service teachers in using digital technology in schools.

Hypothesis 10: behavioural intention influences the use behaviour in constraining the pre-service teachers in using digital technology in schools.

The results in Table 4.2.3b indicates that behavioural intention affects users' use behaviour in digital technologies positively $(\beta=0.616, p=.000)$. Hence, hypothesis 9 is supported and hypothesis 10 is denied. This means that the more intention that the users' had in using the digital technologies, the more common their use behaviour in digital technologies.

\section{THE FINDINGS OF THE RESEARCH DISCOVERED THE FOLLOWINGS:}

- The pre-service teachers have a perception that their performance will increase if they are using digital technologies in school. Hence, their intention in using the digital technologies also increase.

- The pre-service teachers have a perception that when digital technologies are hard and complicated to use, their intention in using the digital technologies in schools will also deplete.

- The pre-service teachers have a perception that when someone who is important to them such as friends, family or educators encourage them to use digital technologies, their intention in using it will escalate.

- The pre-service teachers have a perception that when they expect that no supports from university or from an individual or a group of people were not received, their intention to use digital technologies in schools will decrease as well.

- The pre-service teachers have a perception that when the more intent that they have in using digital technologies, the more frequent they will use the digital technologies in schools

\section{DISCUSSIONS}

The findings of this research supported some of the modified utaut models in determining determinants that encourage or constrain digital technologies usage among pre-service teachers in national university of malaysia (ukm). According to the result, the modified utaut supported performance expectancy, social influence and behavioural intention whereas effort expectancy and facilitating conditions are denied. Nevertheless, the internal relation in performance expectancy, effort expectancy, social influence, facilitating condition, behavioural intention and use behaviour are strong as indicated by cronbach's alpha $(>0.70)$. 
INTERNATIONAL JOURNAL OF ACADEMIC RESEARCH IN PROGRESSIVE EDUCATION AND DEVELOPMENT

Vol. 7, No. 4, 2018, E-ISSN: 2226-6348 @ 2018 HRMARS

The findings also suggested that the pre-service teachers in ukm are greatly influenced by performance expectancy and social influence in determining their intention to use the digital technologies in schools. Findings also suggested that the more intention they had in using the digital technologies, the more common it will be for them to really implement the digital technologies in schools. However, this does not mean that other independent variables did not significantly influence the dependent variable. The findings could be different if a greater sample of the population is involved and if the questionnaire is distributed equally to the respondents.

Therefore, the researcher would like to suggest that the university increases their support in facilitating conditions such as providing the digital technologies needed by the students to increase their use of digital technologies. Furthermore, the researcher would also like to suggest that the students to seek help from exact sources if they were faced with difficulties in handling digital technologies.

\section{Conclusion}

The researcher suggested that this study is further studied by including a bigger sample of the population in the UKM. Other than that, the researcher also recommended implying the same modified model theory of UTAUT that the researcher had used in this study to conduct further studies regarding technology. Furthermore, the researcher also suggested focusing more on the 4th year students of Faculty of Education (FPEND) as they were ongoing practical to be a teacher. Hence, they could give more accurate answers as they already had a few weeks of experience in being a teacher. Moreover, involving students from other faculties and universities is also suggested as it would give more reliable results and conclusion.

\section{REFERENCES}

Baba, A. (1997). Statistik penyelidikan dalam pendidikan dan sains sosial. Bangi: publisher national University of Malaysia.

Attuquayefio, S. N., \& Addo, H. (2014). Using the utaut model to analyze students' ict adoptation. International journal of education and development using information and communication technology (ijedict), 2014, vol. 10, issue 3, pp. 75-86.

Files.eric.ed.gov/fulltext/ej1059042.pdf [23 november 2016].

Baltaci-goktalay, S., \& ozdilek, Z. (2010). Pre-service teachers' perceptions about web 2.0 technologies. Procedia social and behavioral sciences 2 (2010) 4737-4741.

Http://www.sciencedirect.com/science/article/pii/s18770428100 08001 [21 october 2016].

Barbie, E. 2000. The Practice of Social Research. 9th Ed. Belmont: C. A. Wadsworth.

Birch \& Irvine, V. (2009). Preservice teachers' acceptance of ict integration in the classroom: applying the utaut model, educational media international vol. 46, no. 4, december 2009, 295315. Http://www.tandfonline.com/doi/abs/10. 1080/09523980903387506 [23 april 2017]. 


\section{INTERNATIONAL JOURNAL OF ACADEMIC RESEARCH IN PROGRESSIVE EDUCATION AND}

\section{DEVELOPMENT}

Vol. 7, No. 4, 2018, E-ISSN: 2226-6348 @ 2018 HRMARS

Eyyam, R., Menevis, i., \& Dogruer, N. (2011). Perceptions of teacher candidates towards web 2.0 technologies. Procedia social and behavioral sciences 15 (2011) 2663-2666. Http://www.sciencedirect.com/science/article/pii/s18770 42811007129 [8 november 2016].

Frankel, J. \& Wallen, N. (2004). How to design and evaluate research in education. 6th ed. New york: mcgraw-hill.

Jackson, S. L. (2006). Research methods and statistics: a critical thinking approach. 2nd ed. Usa: thomson wadsworth.

Kline, P. 1999. The Handbook of Psychological Testing. 2nd Ed. London: Psychology Press.

Hennessy, S., Ruthven, K., \& Brindley, S. (2005). Teacher perspectives on integrating ict into subject teaching: commitment, constraints, caution and change. J. Curriculum studies, in press. Http://www.academia.edu/download/32290726/t_w_i_5.pdf [22 october 2016].

Levin, T., \& Wadmany, R. (2008). Teachers' views on factors affecting effective integration of information technology in the classroom: developmental scenery. Jl. Of technology and teacher education (2008) 16(2), 233-263

Ramasamy, S.R. (2006). Teachers' Competency and Attitude to the Uptake of ICT in the Teaching of English: A Case Study. Bangi: Publisher National University of Malaysia.

Al-shafi, S., \& Weerakkody, V. (2009). Understanding citizens' behavioural intention in the adoption of e-government services in the state of qatar. 17th european conference on information systems.

Al-shehri, M. A. (2012). Using the utaut model to determine factors affecting acceptance and use of e-government services in the kingdom of saudi arabia. Doctoral thesis, school of information and communication technology science, environment, engineering and technology group, university of griffith.

Tan, P. J. B. (2013). Applying the utaut to understand factors affecting the use of english elearning websites in taiwan. Sage open october-december 2013: 1 -12 http://journals.sagepub.com/doi/full/10.1177/2158244013503837 [7 may 2017].

Thomas, T. D., Singh, I., \& Gaffar, K. (2013). The utility of the utaut model in explaining mobile learning adoption in higher education in guyana. International journal of education and development using information and communication technology. (ijedict), 2013, vol. 9, issue 3, pp. 71-85.

Teo, T. (2010). A path analysis of pre-service teachers' attitudes to computer use: applying and extending the technology acceptance model in an educational context. Interactive learning environments vol. 18 , no. 1 , march $2010,65-79$. 
Teo, T., \& Noyes, J. (2014). Explaining the intention to use technology among pre- service teachers: a multi-group analysis of the unified theory of acceptance and use of technology. Interactive learning environments, 2014 vol. 22, no. 1, 51-66. Http://www.tandfonline.com/doi/abs/10.1080/10494820.2011.641674 [29 april 2017].

Venkatesh, V., Morris, M., Davis, G., \& Davis, F. (2003). User acceptance of information technology: toward a unified view. Mis quarterly, 27, 425-478. Https://www.jstor.org/stable/30036540 [11 november 2016].

Wiersma, W. (2000). Research methods in education. An introduction. London: allyn \& bacon.

Wong, Kung-Teck, Teo, T., \& Russo, S. (2012). Influence of Gender and Computer Teaching Efficacy on Computer Acceptance among Malaysian Student Teachers: An Extended Technology Acceptance Model. Australasian Journal of Educational Technology 2012, 28(7), 1190-1207 https://ajet.org.au/index.php/AJET/article/view/796 [22 October 2016]. 